\title{
Impact Analysis of System of Rice Intensification in Farmers Field
}

\author{
R. K. Dwivedi ${ }^{1 *}$, D. K. Tiwari ${ }^{2}$ and Rajesh Khavse ${ }^{1}$ \\ ${ }^{1} J N K V V$. Krishi Vigyan Kendra Damoh (M.P.), India \\ ${ }^{2} R V S K V V$. Krishi Vigyan Kendra Badwani (M.P.), India \\ *Corresponding author
}

\section{A B S T R A C T}

Keywords

Front Line

Demonstration,

Farmers Practices,

Improved Practices,

SRI, Rice

Article Info

Accepted:

12 December 2020

Available Online:

10 January 2021
The front line demonstration on system of Rice Intensification, were conducted on farmers field of Damoh District during Kharif of 2015-16 and 2016-17 at two different location under irrigated condition. Prevailing farmer's practices were treated as control for comparison with improved practice i.e transplanting of rice in single seedling at two leaf stage (8-12 days) at a distance of $25 \mathrm{~cm}$ or more in a square. The result of front line demonstration shows a greater impact on farming community due to significant increase in crop yield greater that farmers practices. The economics and benefit cost ratio of both farmers practices (FP) and Improved practices (IP) were worked out. The No. of effective tillers and grain per penicle were found lower (15/plant and 68/penicle) in FP and found higher (35/plant and 112/penicle) in IP. An average of Rs. 61000/ha was recorded net profit under IP, where It was Rs. 22200/ha under FP. Benefit cost ratio was 2.65 under IP, where it was 1.88 under FP. By introducing the improved technology i.e. SRI. Yield potential and net income from rice cultivation can be enhanced to a great extent with increase in the income level of the farming community of the District.

\section{Introduction}

Rice (Oryza sativa) is the principal food for more than 50\% people and contributes about one-fifth to the total calories consumption of the world. The statistics showed that during the crop year 2016-17 india produced 110.15 million metric tonnes of milled rice from 43.19 million ha area, making the country the world's second largest producer of rice. To meet the food and nutritional requirement, India alone would need about 156 metric tonne of rice by 2030 at an annual increment of 3 metric tonnes in the current rice production. There are several constraints to achieve desired potential of rice but in SRI methods help increase fields by over 50\% while using $40 \%$ less water than conventional method. The SRI methods increase yield the productivity of water since yield can double or more with only half as much water, the productivity of water in greatly increased this is especially important in countries or places where water is becoming scarcer.

In India, the green revolution was oriented toward high input usage particularly, fertilizer, water and plant protection chemical, 
As a result of excessive use of inputs, the yield also stagnated in many part of rice growing region in India. Through technological break through to meet the growing demand. Hence some improved management practices like SRI was implemented in many part of India SRI can be a most suitable method of rice cultivation to poor farmers who have relatively more labour than land and capital.

\section{Materials and Methods}

The present study is a part of mandatory programme of Krishi vigyan Kendra Damoh (M.P). participatory rural appraisal (PRA), group discussion and transect walk were followed to explore the detail information of study area and between technology intervention, HRD, component (Training/ Kisan mela /sangosthi /field day etc) were also include to excel the farmers understanding and skill about the demonstrated technology on transplanting of rice in single seedling at two leaf stage (8-12 days) at a distance of $25 \mathrm{~cm}$ or more in square i.e system of rice Intensification method of transplanting. The front line demonstration conduct in twenty four farmers Held at Bandakpur and Halgaj Village of Damoh District during Kharif 2015-16 and 2016-17. Under Improved practice (SRI) plots use of SRI method of transplanting in cvIR64. Other hand in farmers practices (FP) i.e 3-4 seedling about 20-25 days old seedling without maintains proper distance. Data on the No of Effective tillers, grain per penicle biological yield, harvest index (Table 1) and Gross return (Rs/ha), Net return (Rs/ha), B;C ratio were computed (Table 2). Finally the extension gap, technology gap and technology index (Table 3) were also calculated.

\section{Results and Discussion}

Frontline demonstration on SRI method of rice transplanting conducted by using most popular Variety IR64 in area 10ha at 24 farmers field in Bandakpur and Halgaj Village of Damoh District. Effective tiller per plant and grain per penicle were found tower 15 tiller/plant and 68 grain per pencile in FP (results Calculated that average of two year) followed by 35 tillers/plant and 112 grains/penicle in improved practices (IP). The same trend found is case of Net profit, an average of Rs 61000/ha was recorded under IP, while it was Rs 22200/ha under FP. Benefit cost Ratio was 2.65 under IP, while it was 1.88 under F,P (Table 2) in Table 3 the extension gap i.e. $28 \mathrm{q} /$ ha during the period of study emphasized the need to educate the farmers through varies means for the adoption of improved technology. The trend of technology gap ranging between 4-8 q/ha reflected farmer's co operation in carrying out demonstration with encouraging results in both the years.

Table.1 Performance of FLD as affected by improved practices (IP) as well as farmers practices (FP) (mean of two year 2015-16 and 2016-17)

\begin{tabular}{|l|l|c|c|}
\hline S. No. & Parameters & \multicolumn{2}{|c|}{ Treatments } \\
\cline { 3 - 4 } & & IP & FP \\
\hline 1. & Effective Tiller/plant (No) & 35 & 15 \\
\hline 2. & Grain/penicle (No) & 112 & 68 \\
\hline 3. & Grain yield (q/ha) & 54 & 26 \\
\hline 4. & Biological yield(q/ha) & 116 & 56 \\
\hline 5. & Harvest Index (\%) & 46.5 & 46.4 \\
\hline
\end{tabular}


Table.2 Economics of FLD as affected by IP as well as FP

\begin{tabular}{|c|c|c|c|c|c|c|c|c|c|c|c|}
\hline \multirow[t]{2}{*}{ Year } & \multicolumn{2}{|c|}{$\begin{array}{l}\text { Yield } \\
\text { q/ha }\end{array}$} & \multirow[t]{2}{*}{$\begin{array}{c}\% \\
\text { increase } \\
\text { over FP }\end{array}$} & \multicolumn{2}{|c|}{$\begin{array}{c}\text { Gross } \\
\text { Expenditure } \\
\text { Rs/ha }\end{array}$} & \multicolumn{2}{|c|}{$\begin{array}{c}\text { Grass income } \\
\text { Rs/ha }\end{array}$} & \multicolumn{2}{|c|}{ Net Profit } & \multicolumn{2}{|c|}{ B.C Ratio } \\
\hline & IP & FP & & IP & FP & IP & FP & IP & FP & IP & FP \\
\hline 2015-16 & 56 & 24 & 133.3 & 36000 & 24000 & 101600 & 43600 & 65600 & 19600 & 2.82 & 1.81 \\
\hline 2016-17 & 52 & 28 & 85.7 & 38000 & 26000 & 94400 & 50800 & 56400 & 24800 & 2.48 & 1.95 \\
\hline mean & 54 & 26 & 109.5 & 37000 & 25000 & 98000 & 47200 & 61000 & 22200 & 2.65 & 1.88 \\
\hline
\end{tabular}

Table.3 Productivity, Technology gap, extension gap and Technology index of SRI as affected by IP as well as FP

\begin{tabular}{|c|c|c|c|c|c|c|c|c|c|}
\hline \multirow[t]{2}{*}{ Year } & \multirow{2}{*}{$\begin{array}{c}\text { Area } \\
\text { (ha) }\end{array}$} & \multirow{2}{*}{$\begin{array}{l}\text { No. of } \\
\text { farmer }\end{array}$} & \multicolumn{3}{|c|}{ Yield $q / h a$} & \multirow{2}{*}{$\begin{array}{c}\% \\
\text { increase } \\
\text { over FP }\end{array}$} & \multirow{2}{*}{$\begin{array}{l}\text { Technology } \\
\text { Gap (q/ha) }\end{array}$} & \multirow{2}{*}{$\begin{array}{c}\text { Extension } \\
\text { Gap } \\
\text { (q/ha) }\end{array}$} & \multirow{2}{*}{$\begin{array}{l}\text { Technology } \\
\text { Index (\%) }\end{array}$} \\
\hline & & & Potential & IP & FP & & & & \\
\hline 2016-17 & 5 & 12 & 60 & 56 & 24 & 133.3 & 4 & 32 & 6.6 \\
\hline 2017-18 & 5 & 12 & 60 & 51 & 28 & 85.7 & 8 & 24 & 13.3 \\
\hline Total /Mean & 10 & 24 & 60 & 54 & 26 & 109.5 & 6 & 28 & 9.9 \\
\hline
\end{tabular}

The technology index showed the feasibility of the demonstrated technology at farmers field. The lower value of technology index, the more is the feasibility of the technology. As such, the reduction in technology index from $6.6 \%$ during $2015-16$ to $13.3 \%$ during 2016-17 exhibited the feasibility of the demonstrated technology in this region.

In conclusion frontline demonstration on transplanting of rice in SRI method was conducted in two village of Damoh District and result conclude the average highest Yield $54 \mathrm{q} / \mathrm{ha}$ in IP fallowed by $26 \mathrm{q} / \mathrm{ha}$ in F.P, means $109.5 \%$ gain. It was observed that the potential yield can be achieved by imparting scientific knowledge to the farmers providing the quality need based input and proper application of SRI method of transplanting. Horizontal spread of improved technology may be achieved by successful implementation of FLD and various extension activities in farmers field.

\section{References}

Gupta.V and Sharma .H.L (2013). Regression analysis for biological yield and harvest index in rice and wheat crops under rice wheat cropping system. $J$ of crop and weed $9(1): 27-33$.

Sahu.G, Murty.K.S and Rai R.S (1980). Effect of Season, nitrogen rate and plant density on harvest index in rice. Oryza 17:28-33.

Singh.V.R singh .S.P Sirazuddin and Tripathi Neeta (2018) Innovations in weed management in rice. Indian farming 68(11):64-67.

Pongle, Seema. Comparative economic analysis of hybrid and improved rice in Balaghat district of Madhya Pradesh. M.Sc. (Ag.) Thesis submitted to J.N.K.V.V Jabalpur (M.P.).

Rajakumar R. Economic and resource impact of System of Rice Intensification (SRI): an empirical dtudy of Pudukkottai district in Tamil Nadu, India. Indian 
Journal of Natural Sciences. 2013; Sivanagaraju P. Traditional and SRI methods 3(18):1311-1345.

Reddy VR, Reddy PP. Reddy MS, Raju DSR. Water use efficiency: A study of System of Rice Intensification (SRI) adoption in Andhra Pradesh. Indian Journal of Agricultural Economics, of paddy cultivation - a comparative economic analysis. M.Sc. (Agri.) Thesis Submitted to University of Agricultural Sciences, Dharwad, Karnataka (India). 2006. 2005; 60(3):458-472.

\section{How to cite this article:}

Dwivedi, R. K., D. K. Tiwari and Rajesh Khavse. 2021. Impact Analysis of System of Rice Intensification in Farmers Field. Int.J.Curr.Microbiol.App.Sci. 10(01): 807-810.

doi: https://doi.org/10.20546/ijcmas.2021.1001.099 